\title{
Friction Coefficients for Arborist Ropes Passing Through Cambium Saver Rings
}

\author{
Brian C. Kane
}

\begin{abstract}
Friction is important in tree care operations; climbers encounter friction when ascending into, working in, and descending out of a tree. Twelve commonly used climbing ropes were tested on cambium saver rings made of three different materials to determine rope on ring static and kinetic friction coefficients. All ropes were tested before any field use. In addition, two ropes were tested after they had been used in the field for 2 years and were evaluated to determine the effect of rope wear on friction. Friction coefficients varied among ropes and ring materials, and surface roughness of ring material was the best predictor of friction coefficient. Used ropes exhibited higher friction coefficients than new ropes and, in most cases, superseded the influence of surface roughness of cambium saver rings. Simple physical models were developed to illustrate how friction coefficients can affect different aspects of tree climbing. There are important implications of these results for further studies on rope friction as it relates to reducing climber fatigue.
\end{abstract}

Key Words. climbing; friction coefficient; rope friction.

Friction is important to climbers while ascending and working in a tree and during rigging operations. The current understanding of friction in the tree care industry is limited to experience with few empiric data to supplement and refine such experience. Beer and Johnston (1988) present a general overview of the concept of belt friction in their introductory text on statics. Previous work described friction as a general principle (Donzelli 1998) and reported friction coefficients for arborist blocks (Donzelli 1999). This study was undertaken to determine static and kinetic friction coefficients for 12 commonly used climbing ropes on three cambium saver ring materials.

Friction is a force that opposes motion when a body moves relative to a solid surface or in a fluid. For the specific case of friction between rope and cambium saver rings, known as rope on ring friction, or rope and a tree branch, known as rope on branch friction (Figure 1), the following equation applies:

$$
\mathrm{T}_{2}=\mathrm{T}_{1} * \exp \left(\mu_{\mathrm{i}}^{*} \theta\right)
$$

where $T_{2}$ is the tensile force applied in the direction that the rope is moving, $T_{1}$ is the tensile force in the rope on the opposite side of the cambium saver rings or a branch, $\mu$ is the friction coefficient, i refers to s or k, depending on whether the rope is stationary (s, static friction coefficient) or sliding over the rings or branch ( $\mathrm{k}$, kinetic friction coefficient), and $\theta$ is the angle of rope contact (in radians) with the rings or branch. The exponential term in equation (1) indicates that $T_{2}$ changes parabolically with either $\mu_{\mathrm{i}}$ or $\theta$. Neither static nor kinetic friction coefficients remain constant for rope friction.

Research on fabrics, fibers, and yarns demonstrates that friction coefficients vary with loads, sliding speeds, and contact pressure, but these variables ordinarily need to vary substantially to influence friction coefficients (Ajayi 1992; Brown and Burgoyne 1999; McKenna et al. 2004; Ramkumar et al. 2004, 2005). Contact pressure depends on the branch or ring radius, rope tension, and a rope's tendency to flatten (Brown and Burgoyne 1999). Investigations of ropes are less common and primarily involve high tensile strength ropes used in mooring applications (Albro and Liu 1985; Nabijou and Hobbs 1995). In most cases, the loads used are either much smaller (e.g., for fiber and yarn testing) or much larger (like in the case of deep sea mooring lines) compared with tree care operations. This makes it difficult to predict friction coefficients for climbing lines.

For ropes (Albro and Liu 1985) and yarns (Brown and Burgoyne 1999), friction coefficients tend to decrease as loads increase. The effect of sliding speed is less consistent, because both increases and decreases in friction coefficient with respect to increasing sliding speed have been reported (Nishimatsu and Sawaki 1984; Hermann et al. 2004). Albro and Liu (1985) found that friction coefficients were inversely proportional to sliding velocity for double-braid polyester ropes on steel sheaves.

Material properties of the surfaces in contact also influence friction coefficients (McKenna et al. 2004). Although the 


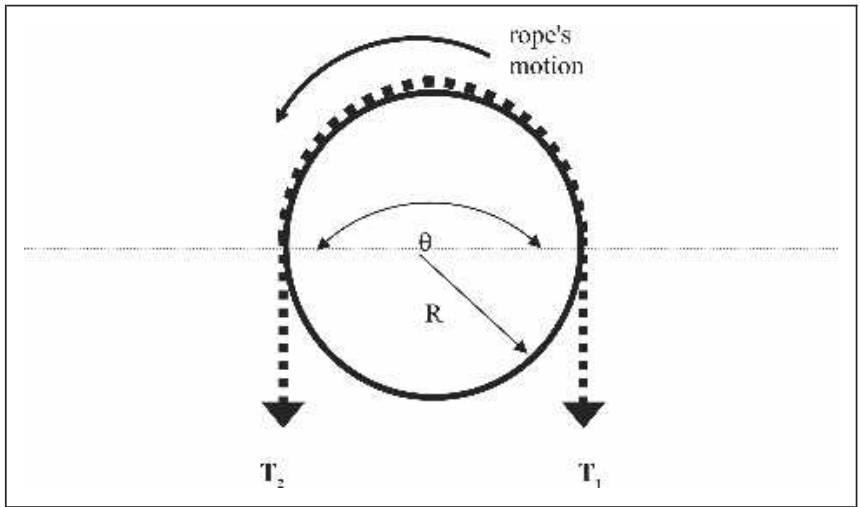

Figure 1. Diagram illustrating equation (1): a rope (dashed line) traveling over a tree branch in crosssection; $T_{2}$ is the tension in the rope in the direction of motion. $T_{1}$ is the tension in the rope on the opposite side of the branch from motion. $\theta$ is the angle of contact, in radians, between the rope and the branch, and $R$ is branch radius.

outer fibers of all arborist ropes are made of polyester, surface coatings on individual rope fibers and the ropes vary widely and may affect friction coefficients. Some rope manufacturers present friction coefficients (Anonymous 2004), but these usually refer to fiber on fiber testing and do not account for the effects of coatings and braiding.

\section{METHODS AND MATERIALS}

Static and kinetic friction coefficients $\left(\mu_{\mathrm{s}}, \mu_{\mathrm{k}}\right.$, respectively) were determined using equation (1) for 12 types of climbing rope on cambium saver rings made of raw aluminum, polished aluminum, and steel. The difference between $\mu_{\mathrm{s}}$ and $\mu_{\mathrm{k}}$ was also calculated for each rope and ring combination. For one randomly selected rope of each rope type, the following attributes were also measured: braid angle, the angle a strand diverges from the long axis of the rope; and braid length, the axial distance between the points where the same strand reappears above itself after having made one rotation. The average of three measurements of braid angle and braid length were taken for each rope while the rope was under the same tension applied during testing. Surface roughness of cambium saver rings was measured with a Starrett Model 3800 profilometer (Starrett Machine Co., Athol, MA). Table 1 provides the names, abbreviations, and pertinent product details for the ropes and cambium saver rings. The length of an individual rope varied from $7.62 \mathrm{~m}(25.15 \mathrm{ft})$ to $45.72 \mathrm{~m}$ $(150.87 \mathrm{ft})$. For each type of rope, at least two and as many as five individual ropes were tested and each individual rope was sampled five times. All ropes and cambium saver rings were tested before any field use. Ropes were sampled by pulling a length of rope through the cambium saver rings before each test. The length of rope that was pulled was determined by a randomly generated number corresponding to the number of lengths to pull through the rings before testing. The random numbers were large enough to ensure that samples were not concentrated in one particular section of the rope. Because each rope was tested on three cambium saver rings, there was incipient wear on the tested sections. Although incipient wear never amounted to more than a few broken fibers, when it coincided with a test, the rope was pulled further through the cambium saver rings to avoid testing that section again.

Static and kinetic friction coefficients and the difference between them were also determined for two types of climbing rope after they had been used in the field. The used ropes had been in service for at least 2 years and were visibly and tangibly "fuzzy" (Figure 2). The two types of used rope were tested on each ring material. At least three individual ropes were tested and each individual rope was sampled five times.

To quantify rope wear, the ropes were photographed and ImageJ software (Wayne Rasband; NIH, Bethesda, MD) was used to determine the surface area for a $12.5 \mathrm{~cm}$ (5 in) length of rope. Four high-resolution (approximately $2000 \mathrm{dpi}$ ) digital images were taken of a randomly selected rope of each type of new rope tested. Images were taken at intervals along the length of the rope; intervals were determined randomly as described above. Each rope was suspended vertically and loaded with $22 \mathrm{~N}(5 \mathrm{lb})$. Because there was greater variation in fuzziness of used ropes, six images were taken of each individual rope. The surface area of four types of used rope was compared with their new counterparts. However, only two types of used rope had enough replicates to be used in the analysis of friction coefficients.

A Buckingham cambium saver (Model 57; Buckingham Manufacturing, Binghamton, NY) was installed over a beam and a spread of $\approx 10 \mathrm{~cm}$ ( 4 in) was maintained between the rings to ensure that the rope legs remained parallel to one another throughout the test. Keeping the rope legs parallel maintains $\theta=\pi$ radians $\left(180^{\circ}\right)$ (equation [1]). During use in the field, the rings of the cambium saver will press against one another, but as long as both legs of rope are parallel, $\theta=$ $\pi$ radians. Cambium saver rings also have a tendency to move vertically relative to one another depending on which direction the rope is moving through the rings. As long as the legs of rope remain parallel and the rings remain in contact, however, $\theta=\pi$ radians.

To avoid overly abrading one area of the rings, they were rotated counterclockwise after testing each rope and two different cambium savers for steel and polished aluminum rings were used. Because only one cambium saver with raw aluminum rings was used, the rings were smoothed more quickly and only five rope types were tested on them. For analysis of the effect of ring material on friction coefficient, only the five rope types tested on all three ring materials were included. 
Table 1. Product details, abbreviations, and measurements for all ropes and cambium saver rings ${ }^{2}$.

\begin{tabular}{|c|c|c|c|c|c|c|c|c|}
\hline Rope & Rope condition & Abbreviation & Manufacturer & Strands & $\begin{array}{l}\text { Number of } \\
\text { ropes tested }\end{array}$ & $\begin{array}{l}\text { Nominal } \\
\text { diameter } \\
(\mathrm{mm} / \mathrm{in})\end{array}$ & $\begin{array}{l}\text { Braid } \\
\text { angle } \\
\left({ }^{\circ}\right)\end{array}$ & $\begin{array}{l}\text { Braid } \\
\text { length } \\
(\mathrm{mm} / \mathrm{in})\end{array}$ \\
\hline Arbor-Plex & New & $\mathrm{AP}$ & Samson & 12 & 3 & $12.7 / 0.51$ & 35 & $4.3 / 0.17$ \\
\hline Arbor-Plex & Used & $\mathrm{Apu}$ & Samson & 12 & 4 & $12.7 / 0.51$ & 35 & $4.3 / 0.17$ \\
\hline Blaze & New & BLAZE & Yale & 24 & 4 & $11.1 / 0.44$ & 45 & $4.1 / 0.16$ \\
\hline Blue Streak & New & BS & Samson & 16 & 3 & $12.7 / 0.51$ & 35 & $4.2 / 0.17$ \\
\hline The Fly & New & FLY & New England & 24 & 4 & $11.1 / 0.44$ & 35 & $4.3 / 0.17$ \\
\hline Safety Blue & New & SB & New England & 16 & 3 & $12.7 / 0.51$ & 30 & $4.3 / 0.17$ \\
\hline $\begin{array}{c}\text { Safety Blue } \\
\text { 3-strand }\end{array}$ & New & SB3 & New England & 3 & 3 & $12.7 / 0.51$ & $\mathrm{~nm}$ & $4.3 / 0.17$ \\
\hline $\begin{array}{l}\text { Safety Blue } \\
\text { High-Vee }\end{array}$ & New & SBHV & New England & 16 & 5 & $12.7 / 0.51$ & 30 & $4.3 / 0.17$ \\
\hline $\begin{array}{l}\text { Safety Blue } \\
\text { High-Vee }\end{array}$ & Used & SBHVu & New England & 16 & 3 & $12.7 / 0.51$ & 30 & $4.3 / 0.17$ \\
\hline Safety-Pro 12 & New & SP & New England & 12 & 4 & $12.7 / 0.51$ & 30 & $4.8 / 0.19$ \\
\hline Tru-Blue & New & $\mathrm{TB}$ & Samson & 12 & 5 & $12.7 / 0.51$ & 45 & $4.1 / 0.16$ \\
\hline Tree Master & New & $\mathrm{TM}$ & Samson & 3 & 3 & $12.7 / 0.51$ & $\mathrm{~nm}$ & $3.9 / 0.16$ \\
\hline XTC Plus & New & XTCP & Yale & 16 & 6 & $12.7 / 0.51$ & 45 & $3.9 / 0.16$ \\
\hline XTC Spearmint & New & XTCS & Yale & 16 & 5 & $12.7 / 0.51$ & 45 & $3.9 / 0.16$ \\
\hline Ring material & Abbreviation & $\begin{array}{l}\text { Ring } \\
\text { condition }\end{array}$ & Manufacturer & $\begin{array}{l}\text { Surface } \\
\text { roughness } \\
(\mu \mathrm{m})\end{array}$ & & & & \\
\hline Aluminum & $\mathrm{AL}$ & New & Buckingham & 1.8 & & & & \\
\hline Polished aluminum & PAL & New & Buckingham & 0.4 & & & & \\
\hline Steel & STEEL & New & Buckingham & 1.4 & & & & \\
\hline
\end{tabular}

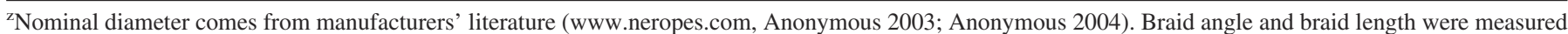
at the same rope tension encountered during testing; the mean of three measurements is shown. Braid angle was not measured (nm) for three-strand ropes. Surface roughness values presented are the mean of three measurements.

A $36 \mathrm{~kg}(79.2 \mathrm{lb})$ mass was attached to one end of the rope being tested. The rope was run through the cambium saver rings, and a Dillon EDXtreme $1134 \mathrm{~kg}(2495 \mathrm{lb})$ capacity dynamometer (Weigh-Tronix, Fairmont, MN) was attached to the other end of the rope. The dynamometer is precise within $1 \mathrm{~kg}(2.2 \mathrm{lb})$ and recorded loads at $0.5 \mathrm{sec}$ intervals. A steadily increasing load was applied to the dynamometer to raise the $36 \mathrm{~kg}(79.2 \mathrm{lb})$ mass a distance of roughly $1.5 \mathrm{~m}$ $(4.95 \mathrm{ft})$. Once the $36 \mathrm{~kg}(79.2 \mathrm{lb})$ began to move upward, it was kept moving at an approximately constant velocity to avoid forces resulting from acceleration. The assumption of constant velocity was confirmed by observing recorded loads against time as shown in Figure 3. The maximum static friction coefficient occurs just before rope movement; the maximum load occurs at the same point. That value was inserted as $T_{2}$ in equation (2), which is a rearranged version of equation (1):

$$
\mu_{\mathrm{s}}=\ln \left(\mathrm{T}_{2} / \mathrm{T}_{1}\right) / \pi
$$

where $\mathrm{s}$ indicates static friction coefficient and the value for $\mathrm{T}_{1}$ is $353 \mathrm{~N}\left(36 \mathrm{~kg} * 9.8 \mathrm{~m} / \mathrm{s}^{2}\right)$. To calculate the kinetic friction coefficient, the average of three to six load measurements after the maximum load was achieved was taken (Figure 3).

To calculate average contact stress $(\sigma)$, the following equation (Brown and Burgoyne 1999) was used:

$$
\sigma=\left(\mathrm{T}_{2}+\mathrm{T}_{1} /(2 * \mathrm{R} * \mathrm{t})\right.
$$

where $\mathrm{R}$ is the radius of a circle drawn around the crosssections of four cambium saver rings as shown in Figure 4, and $t$ is the thickness of the rope where it exits the rings. $t$ was measured under the same rope tension that occurred during the tests.

Analysis of variance (ANOVA) was used to investigate the effect of rope manufacturer, type of rope, rope condition, rope construction (the number of strands braided together to form the rope), and ring material on static and kinetic friction coefficients and the difference between them. ANOVA was also used to test for differences in surface area between new and used ropes. To separate means among the main effects (rope type, number of strands, and ring material), the least significant difference method with Tukey's HSD adjustment was used. 


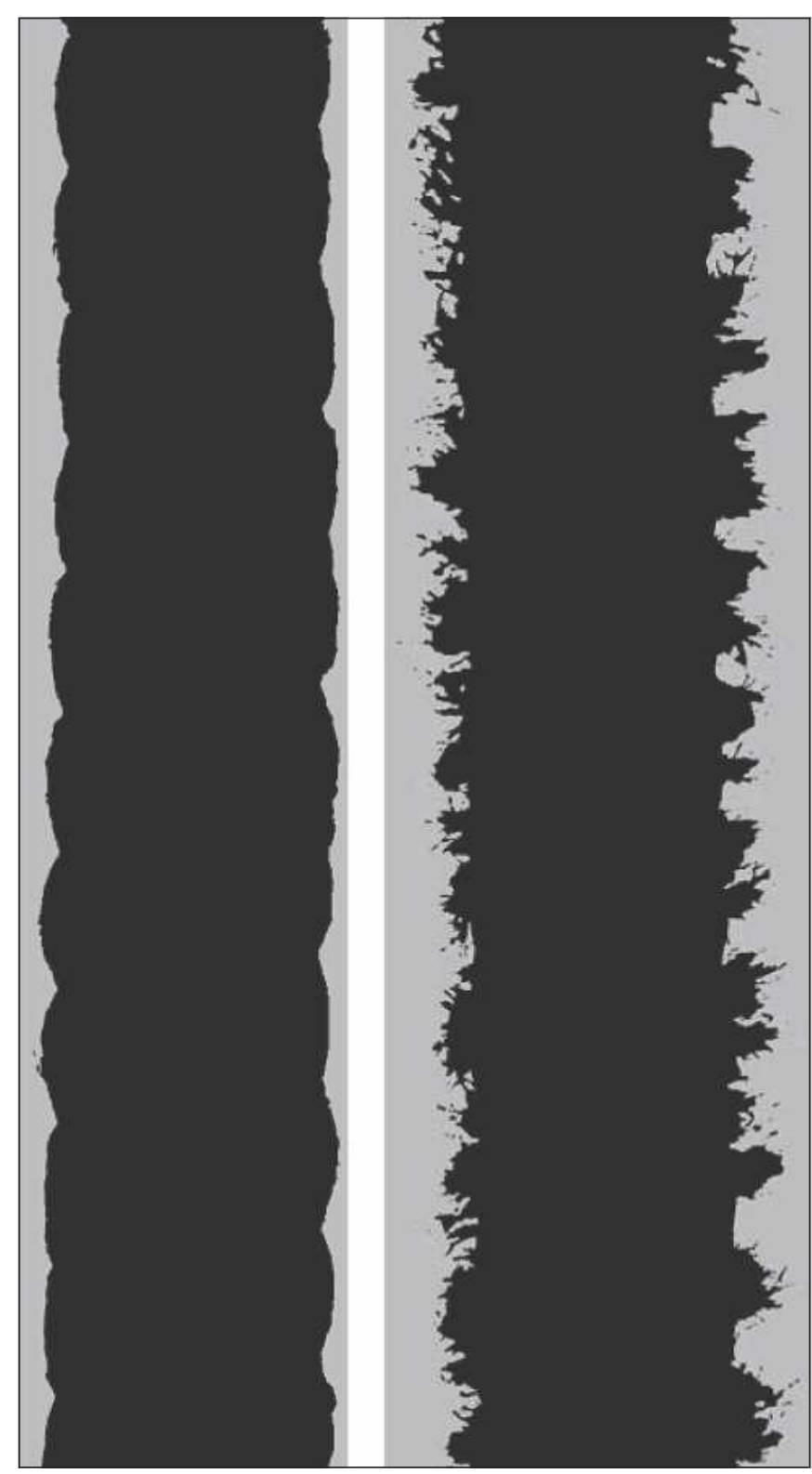

Figure 2. Segmented images of new (left) and used (right) Samson Arbor-plex 12-strand rope used to measure rope surface area. The length of each rope section is $12.5 \mathrm{~cm}$ (5 in).

Regression analysis was used to determine the relationship between friction coefficients and rope characteristics such as contact stress, braid angle, braid length, surface area, and rope construction. Regression analysis was also used to determine the relationship between friction coefficients and surface roughness of cambium saver rings.

\section{RESULTS AND DISCUSSION}

Friction is a complex phenomenon influenced by many variables (McKenna et al. 2004). Neither rope manufacturer nor

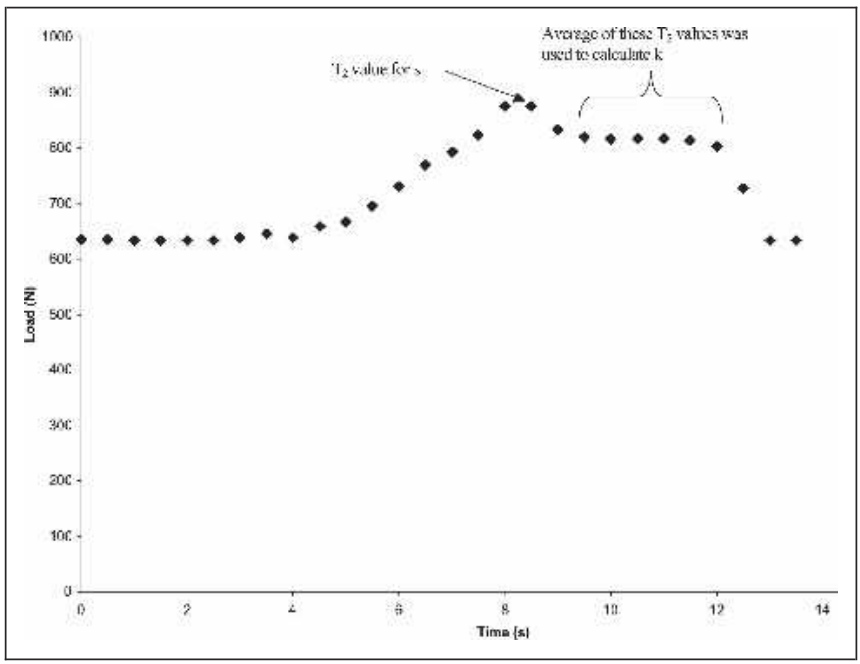

Figure 3. Plot of load against time indicating peak load (s, static friction) and the reduction in load corresponding to $k$, kinetic friction. $T_{2}$ is found in equation (2) in the text. The points correspond to the graph predicted by belt friction theory. For example, see Figure 8.1 in Beer and Johnston (1988).

rope construction consistently influenced static and kinetic friction coefficients (Table 2). Unless otherwise noted, the results reported subsequently reflect comparisons only among ropes of the same construction. This arrangement corre-

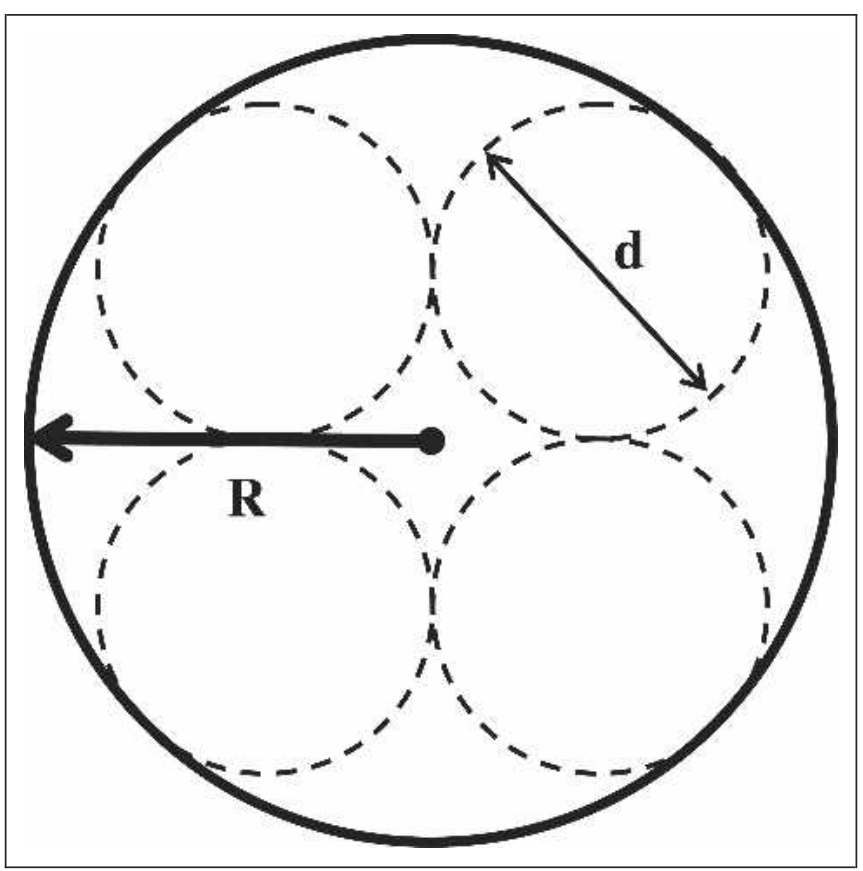

Figure 4. Determination of radius $(R)$ used in equation (3) for contact stress (from Brown and Burgoyne's (1999) formula), in which $d$ is the diameter of the cross-section of a cambium saver ring. 
Table 2. Mean static $\left(\mu_{s}\right)$ and kinetic $\left(\mu_{K}\right)$ friction coefficients and the difference between them $\left(\mu_{s}-\mu_{K}\right.$ ) (followed by standard errors in parentheses) for each rope and ring combination; only new ropes are included ${ }^{2}$.

\begin{tabular}{|c|c|c|c|c|c|}
\hline Rope & Ring & $\mu_{\mathrm{S}}$ & $\mu_{\mathrm{K}}$ & $\mu_{S}-\mu_{K}$ & Area $\left(\mathrm{cm}^{2} / \mathrm{in}^{2}\right)$ \\
\hline AP & PAL & $0.24(0.003) \mathrm{a}$ & $0.21(0.002) \mathrm{a}$ & $0.030(0.0024)^{*}$ & $21.10(3.226 / 0.516)$ \\
\hline $\mathrm{AP}$ & STEEL & $0.26(0.003) b$ & $0.23(0.002) \mathrm{b}$ & $0.026(0.0024)^{*}$ & \\
\hline BLAZE & PAL & $0.21(0.003) \mathrm{a}$ & $0.20(0.002) \mathrm{a}$ & $0.014(0.0020)^{*}$ & \\
\hline BLAZE & STEEL & $0.24(0.003) b$ & $0.22(0.002) b$ & $0.021(0.0021)^{*}$ & \\
\hline $\mathrm{BS}$ & PAL & $0.23(0.003) \mathrm{a}$ & $0.22(0.002) \mathrm{a}$ & $0.014(0.0023)^{*}$ & $22.19(0.147 / 0.024)$ \\
\hline BS & STEEL & $0.27(0.003) b$ & $0.25(0.002) \mathrm{b}$ & $0.017(0.0024)^{*}$ & \\
\hline FLY & $\mathrm{AL}$ & $0.29(0.004) \mathrm{a}$ & $0.28(0.003) \mathrm{a}$ & $0.015(0.0030)^{*}$ & \\
\hline FLY & PAL & $0.27(0.003) b$ & $0.25(0.002) \mathrm{b}$ & $0.018(0.0020)^{*}$ & \\
\hline FLY & STEEL & $0.29(0.003) \mathrm{a}$ & $0.27(0.002) \mathrm{a}$ & $0.016(0.0020)^{*}$ & \\
\hline SB & PAL & $0.23(0.003) \mathrm{a}$ & $0.22(0.002) \mathrm{a}$ & $0.018(0.0023)^{*}$ & \\
\hline SB & STEEL & $0.25(0.003) \mathrm{b}$ & $0.24(0.002) \mathrm{b}$ & $0.013(0.0025)^{*}$ & \\
\hline SB3 & PAL & $0.23(0.003) \mathrm{a}$ & $0.21(0.002) \mathrm{a}$ & $0.019(0.0024) *$ & \\
\hline SB3 & STEEL & $0.25(0.003) \mathrm{a}$ & $0.23(0.002) b$ & $0.016(0.0024) *$ & \\
\hline SBHV & $\mathrm{AL}$ & $0.26(0.002) \mathrm{a}$ & $0.24(0.002) \mathrm{a}$ & $0.020(0.0019) *$ & $19.68(0.806 / 0.129)$ \\
\hline SBHV & PAL & $0.23(0.002) \mathrm{b}$ & $0.20(0.002) \mathrm{b}$ & $0.022(0.0018)^{*}$ & \\
\hline SBHV & STEEL & $0.23(0.002) \mathrm{b}$ & $0.22(0.002) \mathrm{c}$ & $0.015(0.0018)^{*}$ & \\
\hline SP & $\mathrm{AL}$ & $0.25(0.004) \mathrm{a}$ & $0.23(0.003) \mathrm{a}$ & $0.020(0.0030)^{*}$ & \\
\hline SP & PAL & $0.22(0.003) b$ & $0.21(0.002) \mathrm{b}$ & $0.012(0.0021)^{*}$ & \\
\hline SP & STEEL & $0.25(0.003) \mathrm{a}$ & $0.24(0.002) \mathrm{a}$ & $0.017(0.0020)^{*}$ & \\
\hline TB & $\mathrm{AL}$ & $0.26(0.002) \mathrm{a}$ & $0.24(0.002) \mathrm{a}$ & $0.018(0.0019) *$ & $21.10(0.677 / 0.108)$ \\
\hline TB & PAL & $0.22(0.002) b$ & $0.20(0.002) \mathrm{b}$ & $0.017(0.0018)^{*}$ & \\
\hline TB & STEEL & $0.23(0.002) \mathrm{c}$ & $0.22(0.002) \mathrm{c}$ & $0.016(0.0018)^{*}$ & \\
\hline TM & PAL & $0.22(0.003) \mathrm{a}$ & $0.22(0.002) \mathrm{a}$ & $0.005(0.0024)$ & \\
\hline $\mathrm{TM}$ & STEEL & $0.25(0.003) \mathrm{b}$ & $0.24(0.002) b$ & $0.007(0.0025)$ & \\
\hline XTCP & PAL & $0.22(0.002) \mathrm{a}$ & $0.21(0.002) \mathrm{a}$ & $0.012(0.0017)^{*}$ & \\
\hline XTCP & STEEL & $0.25(0.002) b$ & $0.23(0.002) \mathrm{b}$ & $0.015(0.0017)^{*}$ & \\
\hline XTCS & $\mathrm{AL}$ & $0.25(0.002) \mathrm{a}$ & $0.23(0.002) \mathrm{a}$ & $0.019(0.0019) *$ & \\
\hline XTCS & PAL & $0.23(0.002) \mathrm{b}$ & $0.21(0.002) \mathrm{b}$ & $0.018(0.0019) *$ & \\
\hline XTCS & STEEL & $0.25(0.002) \mathrm{a}$ & $0.23(0.002) \mathrm{a}$ & $0.015(0.0018)^{*}$ & \\
\hline
\end{tabular}

${ }^{\mathrm{z}}$ For each type of rope, means followed by different letters indicate a difference between rings at $P<0.01$. An asterisk following $\mu_{\mathrm{S}}-\mu_{\mathrm{K}}$ values indicates that the static and kinetic friction coefficients are different at $P<0.01$. Area refers to rope surface area, which was not measured for all ropes and is only listed in the first ring type for convenience. See Table 1 for rope and ring abbreviations.

sponds to climbers' preference to use different types of rope for different operations, e.g., climbing versus rigging.

\section{Comparisons Among New Ropes}

The kinetic friction coefficient was lower than the static friction coefficient for each new rope except TM (Table 2). For all ropes, the mean kinetic friction coefficient value was $93 \%$ of the mean value for static friction coefficient, which is similar to the $90 \%$ value reported for wire ropes (Nabijou and Hobbs 1995). It was, however, greater than the $80 \%$ guideline suggested by Slater (1977). The rope with the greatest disparity between kinetic and static friction coefficients was AP, for which the kinetic friction coefficient was $87 \%$ of static friction coefficient. TM showed the smallest disparity between static and kinetic friction coefficients; the kinetic friction coefficient was $98 \%$ of the static friction coefficient. Ring material did not influence the calculated difference between static and kinetic friction coefficients.
Both static and kinetic friction coefficients differed among new ropes (Table 3), although no single rope characteristic clearly explained the differences. Braid angle influenced static $\left(P=0.02, \mathrm{R}^{2}=0.19\right)$ and kinetic $\left(P=0.02, \mathrm{R}^{2}=\right.$ 0.20 ) friction coefficients (Figure 5), but not consistently (Table 3). It was expected that braid length would influence friction coefficients because it affects the hardness of the rope's lay, which, in turn, affects surface pressure on the rope as it passes through the rings. The results do not support that expectation.

For most ropes, differences among static friction coefficients mirrored differences among kinetic friction coefficients (Table 3). Ring material appeared to influence exceptions to this pattern, which only occurred for PAL rings, to which the following results apply. AP apparently had greater static but not kinetic friction coefficients than TB because the static friction coefficient was much greater than the kinetic friction coefficient for AP. There was a comparatively 
Table 3. $P$ values for comparisons of static $\left(\mu_{\mathrm{s}}\right)$ and kinetic $\left(\mu_{K}\right)$ friction coefficients and the difference between them $\left(\mu_{s}-\mu_{k}\right)$ among rope types within each ring material ${ }^{2}$.

\begin{tabular}{|c|c|c|c|}
\hline & $\mu_{\mathrm{s}}$ & $\mu_{\mathrm{K}}$ & $\mu_{\mathrm{S}}-\mu_{\mathrm{K}}$ \\
\hline \multicolumn{4}{|l|}{$\mathrm{AL}$ rings } \\
\hline $\mathrm{SBHV}>\mathrm{XTCS}$ & 0.0033 & $<0.0001$ & 1.0000 \\
\hline $\mathrm{SP}<\mathrm{TB}$ & 1.0000 & 0.9917 & 1.0000 \\
\hline \multicolumn{4}{|l|}{$\mathrm{PAL}$ rings } \\
\hline $\mathrm{AP}>\mathrm{SP}$ & 0.1752 & 0.9849 & $<0.0001$ \\
\hline $\mathrm{AP}>\mathrm{TB}$ & 0.0005 & 0.9875 & 0.0051 \\
\hline BLAZE < FLY & $<0.0001$ & $<0.0001$ & 1.0000 \\
\hline $\mathrm{BS}>\mathrm{SB}$ & 1.0000 & 1.0000 & 1.0000 \\
\hline $\mathrm{BS}>\mathrm{SBHV}$ & 0.9530 & $<0.0001$ & 0.4871 \\
\hline $\mathrm{BS}>\mathrm{XTCP}$ & 0.1195 & 0.1086 & 1.0000 \\
\hline BS > XTCS & 0.9998 & 0.4046 & 1.0000 \\
\hline $\mathrm{SB}>\mathrm{SBHV}$ & 0.8949 & 0.0014 & 0.9931 \\
\hline $\mathrm{SB}>\mathrm{XTCP}$ & 0.0707 & 0.6992 & 0.9270 \\
\hline SB $>$ XTCS & 0.9987 & 0.9582 & 1.0000 \\
\hline SBHV > XTCP & 0.9981 & 0.5973 & 0.0042 \\
\hline SBHV > XTCS & 1.0000 & 0.3399 & 0.9726 \\
\hline $\mathrm{SP}>\mathrm{TB}$ & 0.9986 & 0.0219 & 0.9792 \\
\hline $\mathrm{TM}<\mathrm{SB} 3$ & 0.9575 & 0.9430 & 0.0048 \\
\hline XTCP $>$ XTCS & 0.8352 & 1.0000 & 0.7963 \\
\hline \multicolumn{4}{|l|}{ STEEL rings } \\
\hline $\mathrm{AP}>\mathrm{SP}$ & 0.9762 & 1.0000 & 0.4921 \\
\hline $\mathrm{AP}>\mathrm{TB}$ & $<0.0001$ & $<0.0001$ & 0.1978 \\
\hline BLAZE < FLY & $<0.0001$ & $<0.0001$ & 0.9906 \\
\hline $\mathrm{BS}>\mathrm{SB}$ & 0.0859 & 0.0139 & 1.0000 \\
\hline $\mathrm{BS}>\mathrm{SBHV}$ & $<0.0001$ & $<0.0001$ & 1.0000 \\
\hline $\mathrm{BS}>\mathrm{XTCP}$ & $<0.0001$ & $<0.0001$ & 1.0000 \\
\hline $\mathrm{BS}>\mathrm{XTCS}$ & $<0.0001$ & $<0.0001$ & 1.0000 \\
\hline SB $>$ SBHV & $<0.0001$ & $<0.0001$ & 1.0000 \\
\hline $\mathrm{SB}>\mathrm{XTCP}$ & 0.9909 & 0.6218 & 1.0000 \\
\hline SB $>$ XTCS & 0.9981 & 0.8546 & 1.0000 \\
\hline SBHV $<$ XTCP & 0.0002 & $<0.0001$ & 1.0000 \\
\hline SBHV $<$ XTCS & 0.0002 & $<0.0001$ & 1.0000 \\
\hline $\mathrm{SP}>\mathrm{TB}$ & $<0.0001$ & $<0.0001$ & 1.0000 \\
\hline $\mathrm{TM}<\mathrm{SB} 3$ & 1.0000 & 0.1984 & 0.5205 \\
\hline XTCP > XTCS & 1.0000 & 1.0000 & 1.0000 \\
\hline
\end{tabular}

${ }^{\mathrm{z}}$ Only ropes of similar construction are compared. Two rope types in the left hand column are separated by $<$ or $>$, which denote that the first rope type is less than or greater than, respectively, the second rope type. The $P$ value indicates whether the difference between rope types was significant. See Table 1 for rope and ring abbreviations and Table 2 for means of $\mu_{S}, \mu_{K}$, and $\mu_{\mathrm{S}}-\mu_{\mathrm{K}}$ for each rope.

smaller difference between static and kinetic friction coefficients for TB (Table 3). Both BS and SB exhibited greater kinetic, but not static, friction coefficients than SBHV. This appears to be the result of the large disparity between static and kinetic friction coefficients for SBHV (Table 3). TB had a greater disparity between static and kinetic friction coefficients than SP, which explains why SP only had a higher kinetic friction coefficient than TB.

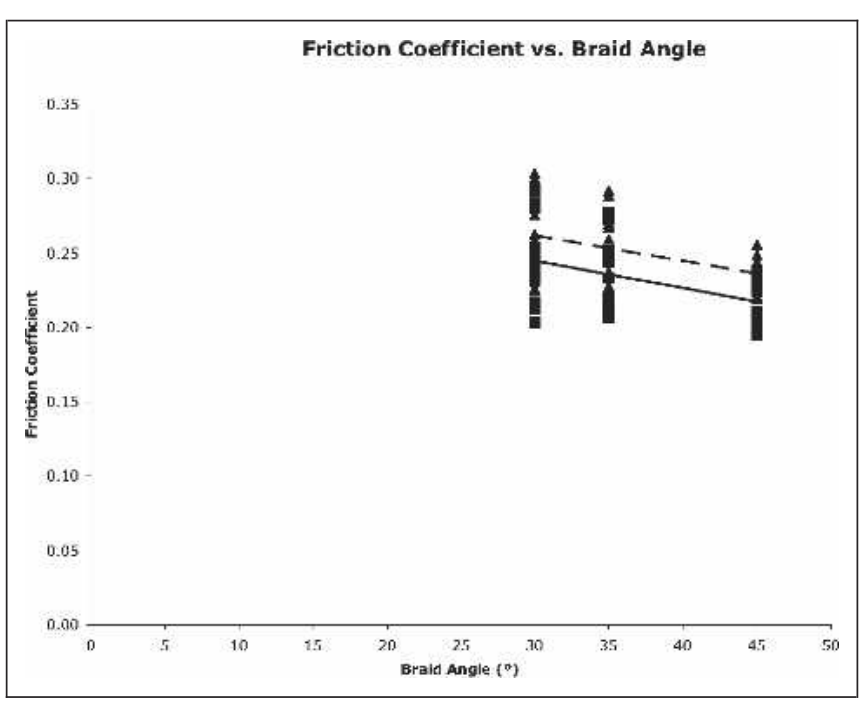

Figure 5. Scatterplot and best fit lines showing the effect of braid angle on static $(\boldsymbol{N})$ and kinetic $(\square)$ friction coefficients. Static friction coefficients $\left(\mu_{\mathrm{s}}\right)$ decrease linearly as braid angle $(\phi)$ increases $\left(\mu_{s}=-0.0017 \phi+0.314, R^{2}=\right.$ $0.19, P=0.02$ ); kinetic friction coefficients $\left(\mu_{K}\right)$ followed the same pattern $\left(\mu_{\mathrm{K}}=-0.0018 \phi+0.299, \mathrm{R}^{2}=0.20, P=\right.$ 0.02 ). Results did not differ by ring material so the figure shows all ring materials.

Although friction coefficients were the same for XTCP and XTCS, they were not consistent between SB and SBHV (Table 3). Both pairs of ropes differ only in the substitution of dyed fibers to construct some of the strands. SB is made of all white strands, whereas strands of SBHV alternate between white and orange. White strands alternate with red or green strands for XTCP and XTCS, respectively. The dyes that fiber manufacturers use may affect friction properties just as they affect strength properties. It is interesting to note that the tensile strength of SB is $10 \%$ greater than that of SBHV (technical data available at www.neropes.com), whereas the tensile strengths of XTCP and XTCS are the same as Yale XTC. XTC is the same rope as XTCP and XTCS except without dyed strands (Anonymous 2003).

\section{Comparisons Among Cambium Saver Ring Materials}

Ring material influenced static friction coefficients among ropes (Table 3). There were only two differences among 15 static friction coefficient comparisons of ropes tested on PAL rings, whereas STEEL rings produced nine differences among the same 15 comparisons. Ring material similarly influenced kinetic friction coefficients (Table 3). There were three differences among 15 kinetic friction coefficient comparisons of ropes tested on PAL rings and 10 differences among the same 15 comparisons of ropes tested on STEEL rings. Although XTCS exhibited higher static and kinetic 
friction coefficients than SBHV on STEEL rings, SBHV produced higher static and kinetic friction coefficients than XTCS on AL rings. This result is probably an aberration, most likely as a result of the fact that previous testing on $\mathrm{AL}$ rings had smoothed the rings, reducing friction. XTCS was the last rope tested on AL rings, which had begun to show incipient wear. There was no difference between friction coefficients for SBHV and XTCS on PAL rings.

The influence of ring material on differences in friction coefficients among ropes appears to be the result of surface roughness differences among rings (Table 1). Surface roughness influenced static $\left(P<0.0001, \mathrm{R}^{2}=0.32\right)$ and kinetic $\left(P<0.0001, \mathrm{R}^{2}=0.32\right)$ friction coefficients, but not the difference between them (Figure 6). PAL rings produced lower static friction coefficients than AL or STEEL rings for all but two ropes; PAL rings produced lower kinetic friction coefficients than AL or STEEL rings for all ropes (Table 2). Presumably because the surface roughness of AL rings is only marginally greater than STEEL rings, AL rings produced higher static and kinetic friction coefficients than STEEL rings for only two ropes (Table 2). Surface roughness and coating material have been shown to predict reliably friction coefficients for ropes on pulley sheaves (Albro et al. 1984).

Both static and kinetic friction coefficients increased in direct proportion to contact stress (Figure 7). This contrasts findings for friction coefficients between Kevlar 49 fibers and aluminum capstans, which decreased parabolically as contact stress between the surfaces increased (Brown and Burgoyne

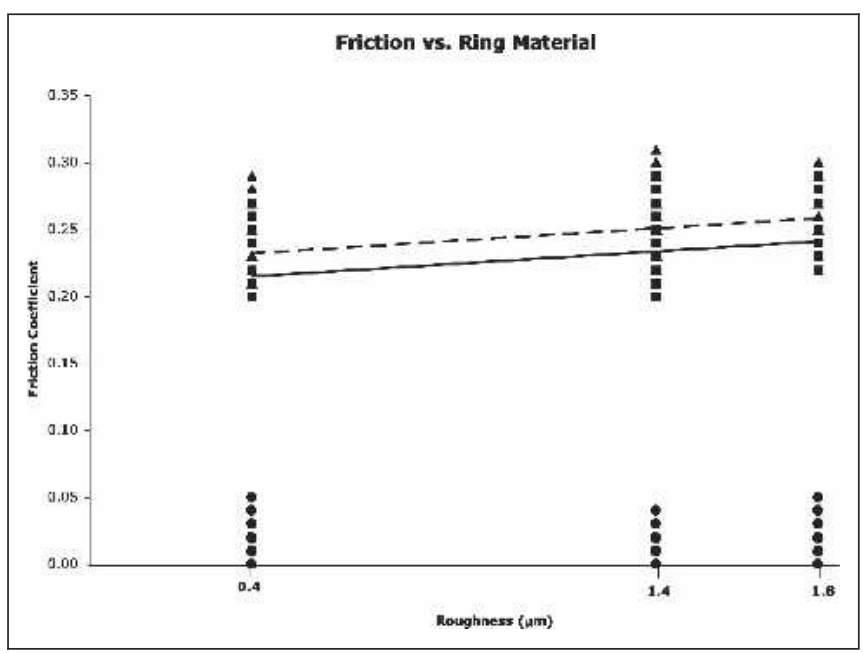

Figure 6. Scatterplot showing the influence of surface roughness $(r)$ on static $(\boldsymbol{U})$ and kinetic $(\boldsymbol{D})$ friction coefficients and the difference between them $(\Theta)$. Best fit lines for static (dashed line) $\left(\mu_{s}=0.0215 r+0.2203, R^{2}=0.32\right.$, $P<0.0001$ ) and kinetic (solid line) friction $\left(\mu_{K}=0.0207 r+\right.$ $\left.0.2044, R^{2}=0.35, P<0.0001\right)$ coefficients are shown; roughness did not influence the difference between them $\left(\mu_{\mathrm{s}}-\mu_{\mathrm{K}}\right)$.

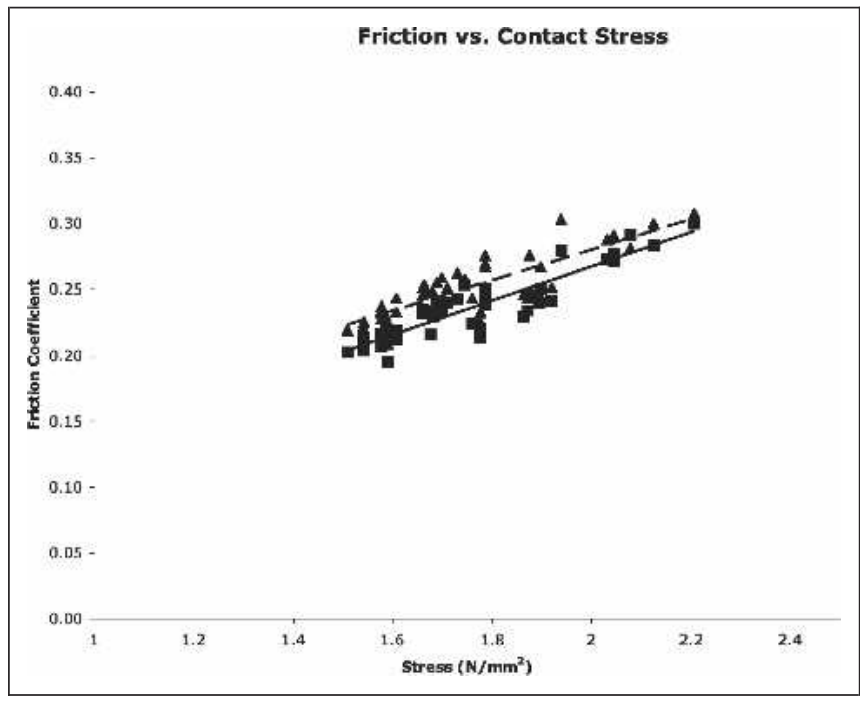

Figure 7. Friction coefficients versus contact stress $(\sigma)$. Best fit line (dashed line) for static friction coefficient $(\Lambda)$ is $\mu_{s}=0.1157 \sigma+0.049\left(R^{2}=0.7176, P<0.0001\right)$. Best fit line (solid line) for kinetic friction coefficient $(\square)$ is $\mu_{K}=$ $0.1296 \sigma+0.0087\left(R^{2}=0.8172, P<0.0001\right)$.

1999). Their results reflect contact stresses that increased orders of magnitude, much greater than the range of contact stresses calculated in the current study.

\section{Used Ropes}

Used ropes exhibited greater surface areas than new ropes of the same type, although used rope areas were more variable (Table 4). Used ropes also produced greater friction coefficients than new ropes (Table 4). This contradicts Albro and Liu's (1985) finding that incipient rope wear on double-braid polyester ropes decreased friction coefficients. No doublebraided ropes were tested in the current study, but it is likely that the contradiction is largely the result of the fact that the ropes tested in the current study were considerably more worn than those tested by Albro and Liu (1985).

With the exception of SBHVu on $\mathrm{AL}$ rings, an increase in surface area for $\mathrm{APu}$ and $\mathrm{SBHVu}$ corresponded to an increase in the static and kinetic friction coefficients compared with AP and SBHV, respectively (Tables 2 and 4). Ring material did not influence this relationship, except, as noted, SBHVu and AL rings. This finding is important because it appears to indicate that an increase in friction resulting from rope wear outweighs other factors that influenced friction on new ropes. It will be helpful to test new and used ropes over branches, which will likely have higher friction coefficients than cambium saver rings, because rope wear might not be as important on rough surfaces like bark.

For all ring materials, APu produced proportionally greater static and kinetic friction coefficients than SBHVu compared with new ropes of each type. This is probably the result of the 
Table 4. Differences among dependent variables, surface area (AREA), static $\left(\mu_{\mathrm{s}}\right)$ and kinetic $\left(\mu_{\mathrm{K}}\right)$ friction coefficients, and the difference between them $\left(\mu_{s}-\mu_{K}\right)$ for used ropes ${ }^{2}$.

\begin{tabular}{llllll}
\hline Dependent variable & Ring & APu & SBHVu & BSu & TBu \\
\hline Area $\left(\mathrm{cm}^{2}\right)$ & N/A & $34.13(1.277) *$ & $30.19(0.477) *$ & $30.97(1.142)^{*}$ & $32.06(0.548) *$ \\
$\mu_{\mathrm{S}}$ & AL & $0.32(0.004) * \mathrm{a}$ & $0.27(0.004) \mathrm{a}$ & & \\
$\mu_{\mathrm{S}}$ & PAL & $0.31(0.004) * \mathrm{a}$ & $0.25(0.004) * \mathrm{a}$ & & \\
$\mu_{\mathrm{S}}$ & STEEL & $0.34(0.003) * \mathrm{~b}$ & $0.28(0.011) * \mathrm{a}$ & & \\
$\mu_{\mathrm{K}}$ & AL & $0.31(0.003) * \mathrm{a}$ & $0.26(0.003) * \mathrm{a}$ & \\
$\mu_{\mathrm{K}}$ & PAL & $0.31(0.003) * \mathrm{a}$ & $0.25(0.003) * \mathrm{a}$ & \\
$\mu_{\mathrm{K}}$ & STEEL & $0.33(0.002) * \mathrm{~b}$ & $0.28(0.009) * \mathrm{a}$ & \\
$\mu_{\mathrm{S}}-\mu_{\mathrm{K}}$ & AL & $0.01(0.002) * \mathrm{a} \dagger$ & $0.01(0.002) * \mathrm{a} \dagger$ & \\
$\mu_{\mathrm{S}}-\mu_{\mathrm{K}}$ & PAL & $0.01(0.002) * \mathrm{a} \dagger$ & $0.00(0.002) * \mathrm{a}$ & \\
$\mu_{\mathrm{S}}-\mu_{\mathrm{K}}$ & STEEL & $0.01(0.001) * \mathrm{a} \dagger$ & $0.01(0.007) * \mathrm{a}$ & & \\
\hline
\end{tabular}

${ }^{\mathrm{z}}$ Means (standard errors are in parentheses) are followed by up to three symbols. The asterisk indicates that the mean for the rope and ring combination is different than the same rope in new condition $(P<0.0001)$. Means for new ropes are presented in Table 2. Different letters following means of a dependent variable within a rope indicate differences among rings $(P<0.01)$ for that dependent variable. Differences between static and kinetic friction coefficients $(P<0.01)$ for each rope and ring combination are indicated by a dagger. BSu and TBu refer to used Blue Streak and Tru-Blue ropes, respectively.

$\mathrm{N} / \mathrm{A}=$ not applicable.

greater increase in surface area (62\%) for APu compared with AP; the surface area of SBHVu was $53 \%$ greater than SBHV.

Static friction coefficients were greater than kinetic friction coefficients for $\mathrm{APu}$ on all rings, but only on $\mathrm{AL}$ rings for SBHVu (Table 4). Although it is not clear why this occurred, the amount of dirt and grit in the used ropes may be partially responsible. APu ropes appeared to be much dirtier than SBHVu ropes based on the amount of dirt that remained on the cambium saver rings after testing. Contaminants such as sand and mud in wire ropes have been shown to increase friction coefficients (Nabijou and Hobbs 1995).

\section{Applications to Tree Work}

\section{Ascending}

The results have important applications to climbing. During dynamic ascents, in which the rope moves relative to the cambium saver rings, a climber must overcome the force $T_{2}$ (equation [2]) to pull him- or herself into the tree. The static friction coefficient applies as the climber exerts maximum force to overcome friction at the cambium saver rings. Once the rope begins to move, the kinetic friction coefficient applies. After the full length of rope has been pulled for a single thrust, the static friction coefficient again applies as the climber holds him- or herself in position before once again exerting maximum force to start the rope moving. At this point, a high static friction coefficient is valuable because it reduces the amount of force the climber needs to apply.

Because the climber's hand and the rope do not move relative to one another, a high static friction coefficient would also be desirable when considering the force a climber needs to apply to grip the rope. The values would likely be different from those determined in this study because different surfaces are involved. Although high static friction coefficients would increase the force a climber must apply to pull him- or herself up, they decrease the amount of force a climber's hand must exert to grip the rope. Climbers prefer to climb on a used rope, although more force is required to overcome rope on ring or rope on branch friction. It seems likely that this is because the large muscles of the legs and back that are used in body-thrusting or dynamic foot-locking can more easily overcome the additional friction between rope and rings. In contrast, the smaller muscles of the climber's hands greatly benefit from the additional friction between rope and hands.

In a body-thrust ascent, a climber must overcome not only his or her own weight, but also the friction imposed by the rope on ring contact. The choice of rope and ring significantly influences the amount of friction, and therefore, the force the climber must apply (Table 5). This is particularly true for used ropes (Table 5). For example, SBHV and TB required little additional force, whereas APu or SBHVu demand considerably more force than a frictionless situation. Percent increase is shown instead of forces because calculating the latter would produce unrealistic values. This would occur because $\mathrm{T}_{2}$ (equation [2]) was modeled assuming each leg of the rope holds one half the climber's weight. In reality, however, during a dynamic ascent, large muscles in the legs and hips lift the climber's weight, so $T_{1}$ is much less than one-half the climber's body weight and $\mathrm{T}_{2}$ would be exponentially lower by equation (1).

Ropes that have high static and low kinetic friction coefficients would be better for ascending because they reduce gripping force and reduce rope on ring friction. Additional testing of used ropes will help to determine if differences between static and kinetic friction are important in practice. The use of gripper gloves may help overcome muscular limitations in the hand, allowing a climber to benefit from reduced friction-coefficient ropes. Further investigation of the ergonomics of climbing, including friction coefficients of ropes on human hands, are necessary to determine how best to minimize climber fatigue. 
Table 5. The percent increase in force a climber needs to apply to pull him- or herself into a tree for each type of rope and ring material compared with a frictionless situation ${ }^{2}$.

\begin{tabular}{|c|c|c|c|c|c|c|}
\hline \multirow[b]{2}{*}{ Rope } & \multicolumn{3}{|c|}{$\mu_{\mathrm{s}}$} & \multicolumn{3}{|c|}{$\mu_{\mathrm{K}}$} \\
\hline & STEEL & PAL & $\mathrm{AL}$ & STEEL & PAL & $\mathrm{AL}$ \\
\hline AP & $126 \%$ & $111 \%$ & $\mathrm{~nm}$ & $108 \%$ & $92 \%$ & $\mathrm{~nm}$ \\
\hline $\mathrm{APu}$ & $191 \%$ & $168 \%$ & $175 \%$ & $179 \%$ & $162 \%$ & $167 \%$ \\
\hline BLAZE & $115 \%$ & $93 \%$ & $\mathrm{~nm}$ & $102 \%$ & $85 \%$ & $\mathrm{~nm}$ \\
\hline $\mathrm{BS}$ & $132 \%$ & $108 \%$ & $\mathrm{~nm}$ & $120 \%$ & $99 \%$ & $\mathrm{~nm}$ \\
\hline FLY & $147 \%$ & $132 \%$ & $151 \%$ & $135 \%$ & $120 \%$ & $139 \%$ \\
\hline SB & $121 \%$ & $108 \%$ & $\mathrm{~nm}$ & $112 \%$ & $98 \%$ & $\mathrm{~nm}$ \\
\hline SB3 & $118 \%$ & $108 \%$ & $\mathrm{~nm}$ & $106 \%$ & $95 \%$ & $\mathrm{~nm}$ \\
\hline SBHV & $107 \%$ & $104 \%$ & $128 \%$ & $98 \%$ & $89 \%$ & $85 \%$ \\
\hline SBHVu & $141 \%$ & $122 \%$ & $132 \%$ & $138 \%$ & $119 \%$ & $126 \%$ \\
\hline SP & $121 \%$ & $102 \%$ & $122 \%$ & $109 \%$ & $95 \%$ & $108 \%$ \\
\hline TB & $108 \%$ & $99 \%$ & $124 \%$ & $98 \%$ & $89 \%$ & $112 \%$ \\
\hline TM & $118 \%$ & $102 \%$ & $\mathrm{~nm}$ & $113 \%$ & $100 \%$ & $\mathrm{~nm}$ \\
\hline ХТСР & $118 \%$ & $100 \%$ & $\mathrm{~nm}$ & $107 \%$ & $93 \%$ & $\mathrm{~nm}$ \\
\hline XTCS & $118 \%$ & $105 \%$ & $119 \%$ & $107 \%$ & $94 \%$ & $107 \%$ \\
\hline
\end{tabular}

${ }^{\mathrm{z}}$ Values for static friction coefficient $\left(\mu_{\mathrm{S}}\right)$ correspond to the maximum increase in force just before the rope moves relative to cambium saver rings. Values for kinetic friction coefficient $\left(\mu_{K}\right)$ correspond to the percent increase in force while the rope moves through the cambium saver rings. "nm" indicates no measurements were taken. See Table 1 for rope and ring abbreviations.

\section{Descending}

During descents, while working in or coming out of a tree, friction also plays an important role. Incorporating "frictionsaving" devices in a climbing system allows the climber to move around the tree more quickly. Such devices are common in tree care supply catalogs and are especially popular at tree-climbing competitions. The term "friction-saving" is misleading; reducing rope on ring friction causes the friction hitch to exert greater force to slow and stop a descent.

To estimate how different rope friction coefficients affect the friction force required at the hitch, known as rope on rope friction, a climber's descent through typical minimum and maximum accelerations encountered in tree climbing was modeled. From equation (4), the additional friction force $\left(T_{1}\right)$ the friction hitch must provide to slow a climber's descent (accelerate in the direction opposite the climber's earthward velocity) was calculated,

$$
\mathrm{T}_{1}=\frac{\mathrm{w} / 2+\mathrm{v}_{0}^{2} / 2 \mathrm{y}_{0} * \mathrm{~m} / 2}{\exp \left(\mu_{k}^{*} \pi\right)}
$$

where $m$ is the climber's mass, $v_{o}$ is the initial velocity, $y_{o}$ is the distance it takes for him or her to stop, and $w$ is his or her weight $\left(\mathrm{w}=\mathrm{m}^{*} \mathrm{~g}\right.$, where $\mathrm{g}$ is the acceleration resulting from gravity, $9.8 \mathrm{~m}^{*} \mathrm{~s}^{-2}$ ). See Appendix A for a derivation of equation (4) and a free-body diagram of the climber used in the model.
Minimum acceleration corresponds to a completely controlled descent and gradually coming to a stop. Maximum acceleration corresponds to an emergency descent out of the tree: a large initial velocity and an abrupt stop. Large accelerations are also caused by hard and precise swings as a climber moves around a tree.

The friction force provided by the hitch when a climber descends decreases as a result of rope on ring friction compared with a situation without friction (Table 6). Greater rope on ring friction reduces rope on rope friction at the hitch. Rope on ring (or rope on branch) friction plays a greater role in reducing rope on rope friction when stopping accelerations are greater because the friction force required to stop is greater. In the absence of friction, the rope tension (T) needed to stop a climber of mass (m) and acceleration (a) is,

$$
\mathrm{T}=\mathrm{m} / 2 *(\mathrm{~g}+\mathrm{a})
$$

During an emergency descent, $\mathrm{a} \approx 30 \mathrm{~m} / \mathrm{s}^{2}$; during a controlled descent, $\mathrm{a} \approx 2 \mathrm{~m} / \mathrm{s}^{2}$ (Appendix A). At greater stopping accelerations, the required friction force supersedes friction coefficient differences among ropes and ring materials.

In addition to reducing cambium abrasion, cambium savers may also reduce rope abrasion. To determine the extent to which this occurs, however, requires further investigation of rope on branch and rope on rope friction. Influences of rope and fiber coatings should also be considered in such investi-

Table 6. The percent decrease in force the friction hitch needs to apply during two different descents from a

\begin{tabular}{|c|c|c|c|c|c|c|}
\hline \multirow[b]{3}{*}{ Rope } & \multicolumn{3}{|c|}{$\mathrm{a}=2 \mathrm{~m} / \mathrm{s}^{2}$} & \multicolumn{3}{|c|}{$\mathrm{a}=30 \mathrm{~m} / \mathrm{s}^{2}$} \\
\hline & \multicolumn{3}{|c|}{$\mu_{\mathrm{K}}$} & \multicolumn{3}{|c|}{$\mu_{\mathrm{K}}$} \\
\hline & STEEL & PAL & $\mathrm{AL}$ & STEEL & PAL & AL \\
\hline $\mathrm{AP}$ & $60 \%$ & $57 \%$ & $\mathrm{~nm}$ & $88 \%$ & $87 \%$ & $\mathrm{~nm}$ \\
\hline AP used & $71 \%$ & $69 \%$ & $69 \%$ & $91 \%$ & $90 \%$ & $90 \%$ \\
\hline BLAZE & $59 \%$ & $55 \%$ & $\mathrm{~nm}$ & $88 \%$ & $87 \%$ & $\mathrm{~nm}$ \\
\hline BS & $62 \%$ & $58 \%$ & $\mathrm{~nm}$ & $88 \%$ & $87 \%$ & $\mathrm{~nm}$ \\
\hline FLY & $65 \%$ & $62 \%$ & $65 \%$ & $89 \%$ & $88 \%$ & $90 \%$ \\
\hline SB & $61 \%$ & $58 \%$ & $\mathrm{~nm}$ & $88 \%$ & $87 \%$ & $\mathrm{~nm}$ \\
\hline SB3 & $60 \%$ & $58 \%$ & $\mathrm{~nm}$ & $88 \%$ & $87 \%$ & $\mathrm{~nm}$ \\
\hline SBHV & $58 \%$ & $56 \%$ & $55 \%$ & $87 \%$ & $87 \%$ & $87 \%$ \\
\hline SBHV used & $65 \%$ & $62 \%$ & $63 \%$ & $89 \%$ & $88 \%$ & $89 \%$ \\
\hline SP & $60 \%$ & $57 \%$ & $60 \%$ & $88 \%$ & $87 \%$ & $88 \%$ \\
\hline TB & $58 \%$ & $56 \%$ & $61 \%$ & $87 \%$ & $87 \%$ & $88 \%$ \\
\hline TM & $61 \%$ & $58 \%$ & $\mathrm{~nm}$ & $88 \%$ & $87 \%$ & $\mathrm{~nm}$ \\
\hline XTCP & $60 \%$ & $57 \%$ & $\mathrm{~nm}$ & $88 \%$ & $87 \%$ & $\mathrm{~nm}$ \\
\hline XTCS & $60 \%$ & $57 \%$ & $60 \%$ & $88 \%$ & $87 \%$ & $88 \%$ \\
\hline
\end{tabular}
tree compared with a frictionless situation ${ }^{2}$.

${ }^{\mathrm{z}}$ During a controlled descent, acceleration (a) during stopping $\approx 2 \mathrm{~m} / \mathrm{s}^{2}$ and friction at the cambium saver rings reduces the stopping force. During an emergency descent or hard swing, acceleration during stopping $\approx 30 \mathrm{~m} / \mathrm{s}^{2}$. "nm" indicates no measurements were taken. See Table 1 for rope and ring abbreviations. $\mu_{\mathrm{K}}$ is the kinetic friction coefficient. 
gations because findings will help manufacturers design ropes that better withstand the rigors of climbing and optimize climber efficiency.

In modeling the stopping forces associated with different accelerations of a climber, four simplifying assumptions were made. First, the rope was considered as not having any mass. Although this is clearly not true, a typical $13 \mathrm{~mm}(0.52 \mathrm{in})$ climbing line weighs between 0.10 and $0.12 \mathrm{~kg} / \mathrm{m}(0.7$ and $0.9 \mathrm{lb} / \mathrm{ft})$, which gives a mass of between 1.5 and $1.9 \mathrm{~kg}(3.3$ and $4.2 \mathrm{lb}$ ) when a climber has descended $15 \mathrm{~m}$ (49.5 ft). For a climber whose mass is $91 \mathrm{~kg}(200.2 \mathrm{lb})$, this is only $4 \%$ of the climber's weight. New, smaller diameter ropes $(11 \mathrm{~mm}$ [0.44 in]) have a mass of $\approx 0.9 \mathrm{~kg} / \mathrm{m}(0.6 \mathrm{lb} / \mathrm{ft})$, so a $15 \mathrm{~m}$ (49.5 ft) length would have a mass of $1.2 \mathrm{~kg}(2.6 \mathrm{lb})$, only $1.5 \%$ of the climber's mass. Second, the rope is assumed not to stretch. All of the ropes do stretch, but the amount is generally less than or equal to $1 \%$ at $445 \mathrm{~N}(100 \mathrm{lb})$ tension (www.neropes.com, Anonymous 2003; Anonymous 2004), the approximate tension that a $91 \mathrm{~kg}(200.2 \mathrm{lb})$ climber would put on each length of rope. Third, acceleration is assumed to be constant as the climber stops, but acceleration varies with time as the climber comes to rest. Fourth, the anchor point in the tree is assumed to be rigid, although there may be some spring effect at the anchor, for example, when a tree limb deflects under load. Modeling the spring effect would be difficult because of the inherent variability of different wood properties, branch sizes, and heights of anchor points. The innate error in our experimental protocol does not seem to justify creating a more precise physical model.

\section{CONCLUSION}

Rope friction is an important consideration in tree care operations that affects climber fatigue, rope abrasion, and rigging operations. Characteristics of both the rope and surface over which it runs influence friction in complex ways that are not always intuitively clear. The important influence of material surface roughness of cambium saver rings on friction coefficients suggests that surface roughness may be more important than rope characteristics, especially considering that there were more differences among ropes tested on rings with a rough surface. Future investigations should test friction on branches with varying degrees of bark roughness. Further studies of used ropes are also necessary because rope wear greatly influenced frictional properties. Finally, ropes should be tested at contact stresses approaching those normally encountered in rigging operations because the results from the current study cannot be extrapolated to such situations.

\section{APPENDIX A}

Equation (4) combines equation (2) with the equations of motion for constant acceleration. In the free-body diagram shown in Figure A1, the climber may be considered as a particle. The tension in the rope at the friction hitch $\left(\mathrm{T}_{2}\right)$ and one-half of the climber's weight (w) act on the climber. The other half of the climber's weight (assuming no friction at the cambium saver rings) is supported by the other half of the rope. To determine $T_{2}$, Newton's Second Law, $\Sigma F=m * a$, can be used. In this case, all forces and motion are vertical, so subscripts denoting direction have been omitted. The positive vertical direction is taken to be toward the top of the page. Integrating the acceleration equation with respect to time $(t)$,

$$
\mathrm{a}=\mathrm{a}(\mathrm{t})
$$

gives the equation for velocity,

$$
\mathrm{v}=\mathrm{a} * \mathrm{t}+\mathrm{C}_{1}
$$

where $C_{1}=v_{o}$, initial velocity, which in this case is $-v_{o}$ because the climber is descending. Integrating the velocity equation with respect to time gives the position equation,

$$
\mathrm{y}=\mathrm{a}^{*} \mathrm{t}^{2} / 2-\mathrm{v}_{\mathrm{o}} * \mathrm{t}+\mathrm{C}_{2}
$$

where $\mathrm{C}_{2}=\mathrm{y}_{\mathrm{o}}$, the initial position. When the climber stops, $\mathrm{v}=0$, so (A2) can be solved for $\mathrm{t}$, substituting $-\mathrm{v}_{\mathrm{o}}$ for $\mathrm{C}_{1}$,

$$
\mathrm{t}=\mathrm{v}_{\mathrm{o}} / \mathrm{a}
$$

Using $\mathrm{y}=0$ as the climber's final position, $\mathrm{t}$ (from [A4]) is substituted into (A3), which is solved for a,

$$
\mathrm{a}=\mathrm{v}_{\mathrm{o}}^{2} / 2 \mathrm{y}_{\mathrm{o}}
$$

Next, $\mathrm{T}_{2}, \mathrm{w}$, and a are substituted into $\sum \mathrm{F}=\mathrm{m} * \mathrm{a}$ :

$$
\mathrm{T}_{2}=\mathrm{w}+\mathrm{m} *\left(\mathrm{v}_{\mathrm{o}}^{2} / 2 \mathrm{y}_{\mathrm{o}}\right)
$$

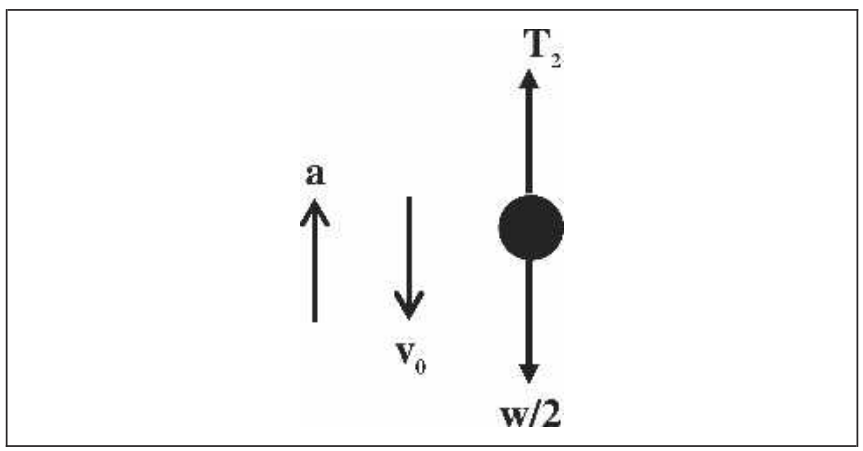

Figure A1. Free body diagram of a climber (black circle) of weight $(w)$ descending at an initial velocity $\left(v_{0}\right)$, then slowing down and stopping as a result of a force $\left(T_{2}\right)$ provided by a friction hitch with acceleration (a). The other half of the climber's weight is accounted for by the second leg of rope that would attach to the saddle. 
where terms have been rearranged to solve for $T_{2}$. Next, $T_{2}$ is substituted into a rearranged version of equation (2):

$$
T_{1}=\frac{w / 2+v_{0}^{2} / 2 y_{0} * m / 2}{\exp \left(\mu_{k}^{*} \pi\right)}
$$

For the gradual descent, $\mathrm{v}_{\mathrm{o}}=1.0 \mathrm{~m} / \mathrm{s}$ and $\mathrm{y}_{\mathrm{o}}=1.0 \mathrm{~m}$; for the emergency descent, $\mathrm{y}_{\mathrm{o}}=2.5 \mathrm{~m} / \mathrm{s}$ and $\mathrm{y}_{\mathrm{o}}=0.1 \mathrm{~m}$. These values were determined by timing and measuring distances during actual descents by a climber.

Acknowledgments. The author thanks Jimmy Cass (Samson Ropes), Jamie Goddard (Yale Cordage), and Bill Shakespeare (New England Ropes) for providing ropes used in this project. The author also thanks Ken Palmer (ArborMaster

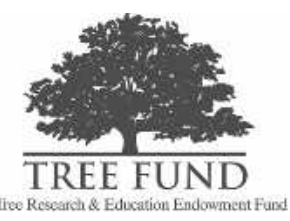
Training) and Buckingham Manufacturing Company for providing cambium savers used in this project. The author also acknowledges Ed Carpenter for helping collect data, Ken James and two anonymous reviewers for suggesting changes to earlier versions of the manuscript, and the TREE Fund for supporting the research through a John Z. Duling grant.

\section{LITERATURE CITED}

Ajayi, J.O. 1992. Fabric smoothness, friction, and handle. Textile Research Journal 62:52-59.

Albro, C.S., and F. Liu. 1985. Effect of groove shape on the frictional hold of a sheave on polyester rope. Journal of Energy Resources Technology 107:103-106.

Albro, C.S., L.F. Nikodem, and D.W. Candy. 1984. Frictional hold on various sheave configurations on synthetic ropes. Naval Civil Engineering Laboratory, contract N62583/83M-RO-54.

Anonymous. 2003. Ropes for Arborists. Yale Cordage. Saco, ME.

- 2004. Professional Arborist Ropes. Samson Rope. Ferndale, WA.

Beer, F.P., and E.R. Johnston. 1988. Vector Mechanics for Engineers: Statics. 5th Ed. McGraw-Hill. New York.

Brown, I.F., and C.J. Burgoyne. 1999. The friction and wear of Kevlar 49 sliding against aluminum at low velocity under high contact pressures. Wear 236:315-327.

Donzelli, P.S. 1998. Engineering concepts for arborists. Arborist News 7:45-48.

1999. Comparison of the frictional properties of several popular arborist blocks. Journal of Arboriculture 25: 61-68.

Hermann, D., S.S. Ramkumar, P. Seshaiyer, and S. Parameswaran. 2004. Frictional study of woven fabrics: The relationship between the friction and velocity of testing. Journal of Applied Polymer Science 92:2420-2424.
McKenna, H.A., J.W.S. Hearle, and N. O'Hear. 2004. Handbook of Fibre Rope Technology. Woodhead Publishing Ltd. Cambridge, UK.

Nabijou, S., and R.E. Hobbs. 1995. Frictional performance of wire and fibre ropes bent over sheaves. Journal of Strain Analysis. 30:45-57.

Nishimatsu, T., and T. Sawaki. 1984. Study on pile fabrics part IV: Investigation of factors affecting frictional properties of pile fabrics. Journal of Textile Machinery Society of Japan. 29:84-88.

Ramkumar, S.S., R. Rajanala, S. Parameswaran, A.K. Sarkar, and A.P.S. Sawhney. 2005. Frictional characterization of polymeric materials-a review. AATCC Review. 5: 17-20.

Ramkumar, S.S., A.S. Umrani, D.C. Shelly, R.W. Tock, S. Parameswaran, and M.L. Smith. 2004. Study of the effect of sliding velocity on the frictional properties of nonwoven fabric substrates. Wear 256:221-225.

Slater, K. 1977. Textile Mechanics. Vol. 1. Textile Institute. Manchester, UK.

Brian C. Kane

125 Holdsworth Hall

University of Massachusetts-Amherst

Amherst, MA 01003, U.S.

bkane@forwild.umass.edu

Résumé. La friction est importante dans les opérations d'entretien des arbres: les élagueurs rencontrent de la friction lorsqu'ils montent dans l'arbre, lorsqu'ils travaillent dedans et lorsqu'ils descendent de ce dernier. Douze cordes communément utilisées ont été testées avec des protège-cambium de trois types différents de matériaux afin de déterminer les coefficients de friction cinétique et de résistance statique sur la corde. Toutes les cordes ont été testées avant leur emploi sur le terrain. De plus, deux cordes ont été testées après qu'elles eurent été utilisées durant deux ans sur le terrain afin de déterminer l'effet de l'usure de la corde par rapport à la friction. Les coefficients de friction variaient entre les cordes ainsi que les protège-cambium et le degré de rugosité des anneaux du protège-cambium était le meilleur prédicateur du coefficient de friction. Les cordes usées présentaient des coefficients de friction plus élevés que les nouvelles cordes et, dans la plupart des cas, cela supplantait l'influence du degré de rugosité des protège-cambium. Des modèles physiques simples ont été développés pour illustrer comment les coefficients de friction peuvent affecter différents aspects de la montée dans l'arbre. Il y a des implications importantes de ces résultats pour des études futures par rapport à la friction de la corde en ce sens que cela est en relation avec une diminution de la fatigue de l'élagueur.

Resumen. La fricción es importante en las operaciones de cuidado de los árboles; los trepadores se encuentran con la fricción cuando ascienden, trabajan y descienden de un árbol. Para determinar los coeficientes de fricción estática y cinética de las cuerdas se probaron doce cuerdas de trepa comúnmente usadas con guardacambios hechos de 3 diferentes materiales Todas las cuerdas fueron probadas antes de cualquier uso en el campo. Además, 2 cuerdas 
fueron probadas después que habían sido usadas en el campo por 2 años, para determinar los efectos del uso de la cuerda sobre la fricción. Los coeficientes de fricción variaron entre las cuerdas y los materiales de los anillos empleados en los guarda-cambios, y la superficie de rugosidad del material de los anillos fue la mejor predicción del coeficiente de fricción. Las cuerdas usadas exhibieron más altos coeficientes de fricción que las cuerdas nuevas y, en la mayoría de los casos, excedieron la influencia de la superficie de rugosidad de los anillos del guarda-cambio. Se desarrollaron modelos físicos simples para ilustrar cómo los coeficientes de fricción pueden afectar diferentes aspectos de la trepa a los árboles. Hay importantes implicaciones de estos resultados para estudios posteriores de fricción de las cuerdas en la medida en que se relacionan con la reducción de la fatiga del trepador.

Zusammenfassung. Reibung ist wichtig bei Baumpflegeoperationen. Kletterer begegnen Reibung beim Aufstieg, bei der Arbeit und beim Abstieg vom Baum. 12 gewöhnliche Kletterseile wurden einem Test mit 3 Kambiumschonern aus unterschiedlichem Material unterzogen, um die Statik des Seils am Ring und die kinetischen Reibungskoeffizienten zu bestimmen. Alle Seile wurden vor dem Feldeinsatz getestet. Zusätzlich wurden 2 Seile nach 2 Jahren Gebrauch getestet und bestimmt, welchen Einfluss das Seilmaterial auf die Reibung hat. Die Reibungskoeffizienten variierten zwischen Seil und Kambiumschonermaterial und die Oberflächenbeschaffenheit war der beste Indikator für Reibung. Gebrauchte Seile zeigten höhere Reibungskoeffizienten als neue, und in den meisten Fällen übertraf es den Einfluss der rauen Oberfläche des Schoners. Einfache physikalische Modelle wurden entwickelt, um zu illustrieren, wie Reibungskoeffizienten verschiedene Aspekte des Kletterns beeinflussen. Es gibt wichtige Implikationen dieser Ergebnisse für weitere Studien an Seilreibung, weil es verbunden ist mit der Reduzierung der Müdigkeit der Kletterer. 